\title{
Accuracy or Bias: Judgment About Others' Intelligence and Moral Identity in A Zero Acquaintance Condition
}

\author{
Alireza Azimpour*, Parisa Abdolrezapour, Saba Ahounbor, Kiamars Zarepour \\ Salman Farsi University of Kazerun, Kazerun, Iran \\ * Corresponding author’s Email: a.azimpour@kazerunsfu.ac.ir
}

\begin{abstract}
Some studies have revealed that most individuals tend to concentrate on others' morality and intelligence at their social perception. The present study aimed to examine the accuracy of these social perceptions in zero acquaintance condition. Nine female students who had high, low or average moral identity/intelligence were considered as targets and the short video clips of their lectures about the same nonrelated subject were presented to other students to judge about them through three studies (total N: 208). The perceptions were full of above-than-chance inaccuracies which were repeated across the three studies. Considering the inaccurate positive account about many targets, accurate perceptions about highly moral/intelligent targets were explained by positive bias to targets than by actual accurate perception. Although beyond such bias, there were some little traces of accuracy particularly in intelligence, it seems that due to many inaccuracies especially about morality, such little traces of accuracy are not much reliable for judgments in settings with zero acquaintance.
\end{abstract}

Keywords: Accuracy of social perception, intelligence, moral identity, zero acquaintance condition

\section{Introduction}

People try to understand others' minds in two different ways: One way is their efforts to propositionally reason about how the mind operates and how the situation affects it. Another way is their perception of others that is intuitive and feels direct and unmediated (Lieberman, 2007). Many investigations in social psychology have been devised to demonstrate injudiciousness, irrationalities, and inaccuracies of the direct and unmediated way of human being's social perceptions (Funder, 1995, Ambady, Bernieri, \& Richeson, 2000; Jussim, 2005). However, in addition to the existence of such pieces of evidence, some studies have confirmed accurate social perceptions of some personality traits at conditions of minimal information or zero acquaintance (for review, see Zebrowitz \& Collins, 1997; Ambady et al., 2000; Nater, \& Zell, 2015). The empirical evidences could not be explained only by self-fulfilling prophecies (Jussim, 1991; Jussim, 2005) or methodological biases (Ambady et al., 2000). Such accuracies about the perception of some traits at zero acquaintance may be explained somewhat by physiological or environmental factors that affect both appearance and psychological traits of targets, or by some psychological variables that affect the face, appearance or behavior of perceived individuals (Zebrowitz \& Collins, 1997; Zebrowitz, Kikuchi \& Fellous, 2007). 
However, there are also many organized inaccuracies and biases in social perception at zero acquaintance. These may be affected by high correlation between perceptions of a trait and another trait; for example, the perceptions of attractiveness or babyfaceness with misperception of trustworthiness (Todorov, Said, Engell, \& Oosterhof, 2008). According to Realistic Accuracy Model (Funder, 1995), for accurate perception of a trait, firstly, the trait must be manifested in some relevant behavior; secondly, that behavior must be observable; thirdly, the perceiver has to be able to detect the behavior; and fourthly, the perceiver must link the detected behavior back to the initial trait. A failure at any point in this process prevents accuracy in judgment. Then, the model can explain why accuracy in person perception is probable and may often be low (Jussim, 2005; Rule, Krendl, Ivcevic \& Ambady, 2013). Ecological theory of social perception (McArthur \& Baron, 1983; Zebrowitz \& Collins, 1997) assumes that perception serves an adaptive function; therefore, external world must provide information to guide biological and social functions. So, human perceptions are more focused on some traits while neglecting other ones. Over attention to trustworthiness and morality can be explained accordingly (Jussim, 2005). In fact, studies have shown that people form their impression based on two clusters of traits: otherprofitable traits such as kindness, honestness, or aggression and self-profitable traits such as intelligence or inefficiency (Wojciszke, Bazinska \& Jaworski, 1998; De Bruin, \& Van Lange, 1999; Wojciszke, 2005). This morality-intelligence (or warmth-competence) distinction helps one understand some different implications of social perception. For instance, "negativity effects" of impression formation relate more to morality and "positivity effects" of it relate more to competence (Martijn, Spears, Van der Pligt \& Jakobs, 1992; Wojciszke et al., 1998; Brambilla, Rusconi, Sacchi, \& Cherubini, 2011). Also, studies have indicated that people more use competence to perceive themselves and morality to perceive others (Wojciszke et al., 1998; De Bruin \& Van Lange, 1999; Brambilla et al., 2011; Brambilla, Sacchi, Rusconi, Cherubini \& Yzerbyt, 2012; Christy, Kim, Vess, Schlegel \& Hicks, 2017). Even when a target had been considered immoral, the competence led to a more negative impression. This phenomenon was attributed to self-interest (Wojciszke, 2005). In fact, people initially want to know whether other's intention is beneficial or harmful; thus, the morality of an individual informs that there is no harm from the individual (Brambilla et al., 2012). Similarly, Christy et al. (2017) pointed that people reported highly moral factious targets as more familiar than highly competent factious ones.

There have been some evidences about accuracy in social perception of intelligence (Borkenau \& Liebler, 1993; Murphy, Hall \& Colvin, 2003; Zebrowitz \& Rhodes, 2004; Murphy, 2007; Ruleet al., 2013). Murphy (2007) in a study showed that although impression managing targets did appear more intelligent to video judges, they could not pretend themselves as more intelligent in the real interaction. Zebrowitz and Rhodes (2004) revealed the role of facial cues and Murphy et al. (2003) and Murphy 
(2007) pointed to the role of nonverbal cues in the accuracy about the perception of intelligence. However, though confirming the accuracy in intelligence perception, there are the potentialities of several biases. For example, Talamas, Mavor and Perrett (2016) have confirmed the danger of a bias according to attractiveness halo effect or Mahmud and Swami (2010) have pointed to the effect of wearing hijab (Islamic head-cover) on the misperception of female targets as lowly intelligent.

At social interactions, accurate judgments about whether a person is honest or deceitful have much importance (Grèzes, Frith \& Passingham, 2004; Linke, Saribay, \& Kleisner, 2016). Some studies (Todorov, Pakrashi, \& Oosterhof, 2009; Rule et al., 2013) have shown the high consensus among perceivers to judge other's trustworthiness even in subliminal and short time opportunity for impression formation (Todorov et al., 2009). Some studies have revealed some facial cues for perceived trustworthiness (Linkeet al., 2016). Some also have pointed to the neural (Etcoff, Ekman, Magee \& Frank, 2000; Grèzeset al., 2004; Delgado, Frank \& Phelps, 2005) or evolutional (Piliavin \& Charng, 1990; Baschetti, 2007) bases of this perception. Etcoffet al., (2000) have found that patients with impaired left hemisphere of the brain could more-than-chance realize the lie from the liar's demeanor. This can be attributed to the importance of the right hemisphere in realizing and understanding nonverbal cues of emotions (Kalat, 2007). Some studies attribute trustworthiness judgment to the function of amygdala (Todorovet al., 2008). Rule et al. (2013) pointed to the role of amygdala in the perceived trustworthiness of faces but not in the actual trustworthiness of individuals' behavior. Some pieces of evidence also showed the females' superiority in accurate social perception of nonverbal cues (Blanck, Rosenthal, Snodgrass, DePaulo\& Zuckerman, 1981; Murphy et al., 2003), but with the exception of detecting cues to deception and lie. Some scholars have explained it by female social role and gender socialization (Baron, Byrne \& Branscombe, 2006).

Many studies have confirmed the evidences for accuracy at social perception of several traits that is conceptually near to morality (Berry, 1990; Borkenau \&Liebler, 1993; Burgoon \& Le Poire, 1999; Zebrowitz \& Collins, 1997; Vogt, Efferson, \& Fehr, 2013). Berry (1990) found evidences of accurate social perception of target's facial photograph at aggression, warmth and honesty. Borkenau and Liebler (1993) showed that strangers could accurately judge conscientiousness of targets. Burgoon and Le Poire (1999) found that by coding the nonverbal cues, participants could predict the intimacy, composure, and formality relational communication. Also, Zebrowitz and Collins (1997), reviewing the previous studies, have shown the accuracy in social perception of conscientiousness and warm/agreeableness and have addressed some cues for accurate perception of them. In addition, Vogt et al. (2013) showed that raters could guess the target's response to a social-moral dilemma by observing the videos; though this accuracy was not considerable. However, Rule et al. (2013), investigating the perceivers' inferences 
about individuals' trustworthiness (either Nobel Peace Prize winners or public figures who had been arrested for breaking the law), have revealed that despite the high consensus in people's social perception of trustworthiness, the judgments were inaccurate. Tappin and McKay (2017) also have pointed to the inaccuracies and biases; the authors found that people irrationally consider others less virtuous and moral than themselves.

Although some of the mentioned investigations have studied the accuracy in social perception of the variables that are conceptually near to morality, there was no investigation studying the underlying moral variables, to the best of the researchers' knowledge. Rule et al. (2013) studied moral or immoral behavior more directly; but moral or immoral behaviors are not fixed variables and are affected by many situational factors (Doris, Stich, Phillips \& Walmsley, 2020). One of the underlying moral variables that has been considered as the core predictor of many other moral-related variables such as moral reasoning, empathy, prosocial behaviors, moral disengagement, aggression and so forth is moral identity (Aquino, Reed, Thau\& Freeman, 2007; Aquino, Freeman, Reed, Lim, \& Felps, 2009; Azimpour, Neasi, ShehniYailagh, Arshadi, \&Beshlideh, 2012a; Azimpour, Shehni-Yailagh, Esfandiyari, Abdollahi, Eslamiyeh, 2017). Moral identity as a social identity (Aquino \& Reed, 2002) is a cognitive schema that a person holds about his or her moral character (Aquino et al., 2009). Considering the predictive role of moral identity among other moral-related variables, confirming the accuracy in its perception can be generalized to the perception of overall morality.

In order to better understand the importance of accuracy in judging others' morality and intelligence, one can refer to employment interviews which are considered as near to zero acquaintance conditions (Morgeson\& Campion, 1997; García, Posthuma \& Colella, 2008; DeGroot \& Gooty, 2009; Schmid Mast, Bangerte, Bulliard \& Aerni, 2011, Linke et al., 2016) and have considerable importance in individuals' future. According to warmth-competence perspective (Wojciszke et. al., 1998; De Bruin, \& Van Lange, 1999; Wojciszke, 2005) humans' impression of other people is based on others' intelligence (competence) and morality (warmth), with the latter being more important (Christy et al., 2017). But how much accurate is the perception of morality and intelligence at zero acquaintance? This study is the first examination of accurate perception in zero acquaintance among Iranians. In this regard, it studies the possibility of generalizing the previous findings in a different population. Also, this is first study to examine the accuracy of judging others with different levels of moral identity. This study aimed to examine the consensus and accuracies in social perception of morality and intelligence and compared accuracies of these two variables.

\section{Study 1}


In this study, university students were asked to examine the intelligence and morality of some other student targets; the targets were either with real high or low intelligence or they were with real high or low morality.

\section{2-1. Method}

In study 1, participants as judges observed nine short video clips from nine targets' lectures andevaluated the targets' morality level (high or low) and intelligence (high or low) by a checklist. The first target had an average intelligence and moral identity, two targets had high levels of intelligence, two targets had low intelligence levels, two targets had a high moral identity and two targets had a low moral identity. The clips were presented to all participants (in several approximately 25 -individual groups). The first clip presented to judges was from theaverage case and the other clips were presented in a random and unorganized order.

In this study, nine targets were asked to speak about university life (an irrelevant subject to the study) for 5 minutes without fore awareness and in the same condition; seven female students, who had been educated to be demure, sat circularly at psychology laboratory and observed the targets while they were speaking. The observers and the targets were blind about the content of the study and character of the targets. The first target had an average intelligence and moral identity, two targets had high levels of intelligence, two targets had low intelligence levels, two targets had a high moral identity and two targets had a low moral identity. The researcher told them that the study was about the attitude of students about university lifestyles. Although the use of this deception was unavoidable, after film-taking, because of moral considerations they were told that this video would be shown to other students and the students, without knowing anything about the speaker, would judge some of your psychological traits. The targets were free to accept or reject this suggestion. Albeit the purpose of the study was somewhat told to them after film-taking, because of the probable bad effect of knowing the reason of their selection on them (for example, knowing about their low intelligence or low morality), the author told them that they were randomly selected.

In study 1, participants as judges observed the nine short video clips from the targets' lectures and decided on targets' morality (high or low) and intelligence (high or low) by a checklist. The clips were presented to all participants (in several approximately 25 -individual groups). The first clip presented to judges was from the average case and the other clips were presented in a random and unorganized order.

\section{2-1-1. Participants (Judges)}

A body of 98 university students from Salman Farsi University of Kazerun, Iran (84 females with the mean age of 21.07; $\mathrm{SD}=3.30$ ) participated in the study as the judges. They were selected through convenient sampling method and participation in the study was absolutely voluntary. 


\section{2-1-2. Target selection}

The 9 targets were selected from participants of a previous investigation at Salman Farsi university of Kazerun (Azimpour, 2019) who were still students (212 undergraduate students, 164 females with the mean age of 18.99, SD: 1.16). Some variables that had been measured in that study were moral identity, general (and nonverbal) intelligence, and social desirability. One of the weaknesses of assessing positive variables such as morality in accuracy perception studies is contacting the assessment with social desirability or pretending to be moral or positive (Fiske, 1993). The Z score of social desirability, internalization subscale of moral identity and intelligence were considered to find the targets. Two targets with the highest $\mathrm{Z}$ score and two targets with the lowest $\mathrm{Z}$ score at intelligence, in the condition that their moral identity and social desirability were between +1 and $-1 \mathrm{Z}$ score, were selected as targets with low and high intelligence. Two targets with the highest $\mathrm{Z}$ score and two targets with the lowest $\mathrm{Z}$ score at moral identity, in the condition that their intelligence and social desirability were between $+1 \mathrm{Z}$ and $-1 \mathrm{Z}$ score were considered as targets with low and high moral identity. In addition, as previously mentioned, a student with an average condition (i.e., Z scores in all the variables were between +1 and 1) was selected as the target whose lecture was first shown to participants. Most participants of the database were females. Hence, and because of the effect of targets' gender on the social perception (Ambady et al., 2000), only female students were considered as targets. In addition, due to the dropout of two students among targets with low intelligence and non-participation of a student among targets with high moral identity, new participants with similar conditions were asked to participate.

\section{2-1-3. Materials}

\section{2-1-3-1. Instruments used for targets selection}

In the previous study, from which the targets of this study were selected (Azimpour, 2019), form A of Cattell's Cultures Fair Test, Scale 3 (Cattell, 1957) had been used to measure intelligence. Cattell and Cattell (1973) reported test-retest reliability $(r=0.69)$ and internal consistency $(\alpha=0.73)$ for the test. Among an Iranian sample, the internal consistency of the measure was found to be 0.67 with KuderRichardson formula and it was 0.55 with split-half method; also, its convergent validities were found to be in the range of 0.5 to 0.68 (YarMohammadian, 2007).

To measure the moral identity, the Internalization subscale (the subscale about the degree to which people's self-concepts center on moral traits) of The Self-Importance of Moral Identity test (Aquino \& Reed, 2002) had been used. Aquino and Reed (2002) reported 0.76 as the Cronbach's alpha of this subscale. In the Persian version of the measure (Azimpour, Neasi, Shehni-Yailagh, Arshadi \& 
Beshlideh. 2014), the Cronbach's alpha for the internalization subscale was 0.79 and its validity with different methods was found to be desirable.

To measure social desirability, the13-item form of Marlowe-Crowne Social Desirability Scale (Reynolds, 1982) was used. This scale was validated in different societies (Verardi, Dahourou, Ah-Kion et. al., 2010). The Persian version of it had a satisfactory criterion-related validity (Najarian\&Soudani, 2001). Azimpour, Neasi, Shehni-Yailagh, and Arshadi (2012b) in a study on a sample of Iranian university students reported an internal consistency of 0.51 that had been calculated by KuderRichardson method.

\section{2-1-3-2. Checklist}

The checklist, which was developed by the authors, contained two sets of binary traits for every target: high intelligent versus low intelligent; kind, helpful and fair versus cold, apathetic and selfish. In addition, there was another choice, i.e., I don't know, for every target. The examiner asked the participants to choose any trait that was near to their perceptions and opt for "I don't know" as the last resort. In case of familiarity between the judge and the target (such as being roommate, classmate, friend and so forth), the participants were asked to write "I know her". In these cases, and in the cases of choosing "I don't know", the item was omitted from the analysis.

\section{2-1-4. Data analysis}

Chi-squared test $\left(\chi^{2}\right)$ of goodness of fit (with Yates correction) was used to study above-than-chance accurate or inaccurate selections. The test was used for any targets, any conditions (low intelligence, high intelligence, low morality and high morality), perception of morality or intelligence totally and for overall accurate judgments. If the actual trait (morality or intelligence) of a target was average, the atchance-level perceptions about the trait would be considered as accurate but above-than-chance inaccurate perceptions of her would be considered as bias. Also, no above-than-chance perceptions of a target's trait with actually different trait would be considered as inaccuracy.

\section{2-2. Findings}

Table 1 shows the above-than-chance frequencies of accurate or inaccurate judgments with $\chi^{2}$ statistical test for each target. As the table shows, even in the average target (target 1), tendencies to judge her at moral/intelligence perspective is above-than-chance ( $\mathrm{ps}<0.01)$; the judges considered her morally high and intellectually low. Judges considered the targets with actually high intelligence (targets5 and 7) as intelligent better-than-chance; however, they also considered them above-than-chance $(\mathrm{ps}<0.01)$ as highly moral. In the targets with a genuine high morality level, judges only realized one of them (i.e., target 9) as highly moral ( $<<0.01)$; and for another case (i.e., target2), the perceptions were not betterthan-chance $(p>0.05)$. The judges also considered both these targets as intelligent ( $p s<0.01)$. In the 
targets with a genuine low intelligence level (i.e., targets 3 and 8), there were not any above-than-chance perception in intelligence ( $p s>0.05)$ but the judges considered them above-than-chance $(p<0.01)$ as highly moral. In the targets with actual low morality level (i.e. targets 4 and 6), one of the targets (i.e., target 6) was considered as lowly moral $(\mathrm{p}<0.01)$ but judgment about morality of the other target $(4)$ was not above-than-chance ( $>>0.05)$. Judges also considered both the targets with low morality as intelligent ( $p<0.01$ for case 4 and $p<0.05$ for case 6 ).

Table 1. Above-than-chance frequencies of judgments for any targets

\begin{tabular}{|c|c|c|c|c|c|c|c|c|c|}
\hline $\begin{array}{l}\text { Targets' } \\
\text { Number } \\
\text { (Targets' } \\
\text { Order) }\end{array}$ & $\begin{array}{l}\text { Actual traits } \\
\text { of target }\end{array}$ & $\begin{array}{l}\text { Judgment } \\
\text { as }\end{array}$ & high & low & $\begin{array}{l}\text { Other } \\
\text { choices† }\end{array}$ & $E$ & $\chi^{2}$ & $\begin{array}{l}\text { Effect size } \\
\text { (Cohen's } \\
W) \dagger \dagger\end{array}$ & $\begin{array}{l}\text { Accuracy } \\
\text { or Bias }\end{array}$ \\
\hline \multirow[t]{2}{*}{1} & \multirow[t]{2}{*}{ Average case } & intelligence & 22 & 58 & 16 & 40 & $7.656 * *$ & .314 & Bias \\
\hline & & morality & 80 & 12 & 5 & 46 & $24.39 * *$ & .515 & Bias \\
\hline \multirow[t]{2}{*}{5} & \multirow{2}{*}{$\begin{array}{l}\text { High } \\
\text { intelligence }\end{array}$} & intelligence & 69 & 29 & 7 & 49 & $7.76^{* *}$ & .281 & Accurate \\
\hline & & morality & 73 & 16 & 9 & 44.5 & $17.62 * *$ & .445 & Bias \\
\hline \multirow[t]{2}{*}{7} & \multirow{2}{*}{$\begin{array}{l}\text { High } \\
\text { intelligence }\end{array}$} & intelligence & 74 & 11 & 13 & 42.5 & $22.61 * *$ & .266 & Accurate \\
\hline & & morality & 89 & 4 & 5 & 46.5 & $37.93 * *$ & .639 & Bias \\
\hline \multirow[t]{2}{*}{3} & \multirow[t]{2}{*}{$\begin{array}{l}\text { Low } \\
\text { intelligence }\end{array}$} & intelligence & 36 & 54 & 8 & 45 & 1.6 & .1333 & $\begin{array}{l}\text { No } \\
\text { Accurate }\end{array}$ \\
\hline & & morality & 84 & 11 & 3 & 47.5 & $28.05 * *$ & .543 & Bias \\
\hline \multirow[t]{2}{*}{8} & \multirow[t]{2}{*}{$\begin{array}{l}\text { Low } \\
\text { intelligence }\end{array}$} & intelligence & 46 & 36 & 16 & 41 & 0.49 & .075 & $\begin{array}{l}\text { No } \\
\text { Accurate }\end{array}$ \\
\hline & & morality & 66 & 20 & 12 & 43 & $11.77 * *$ & .366 & Bias \\
\hline \multirow[t]{2}{*}{2} & \multirow[t]{2}{*}{ High morality } & intelligence & 65 & 22 & 11 & 43.5 & $10.138 * *$ & .341 & Bias \\
\hline & & morality & 33 & 57 & 8 & 45 & 2.93 & .18 & $\begin{array}{l}\text { No } \\
\text { Accurate }\end{array}$ \\
\hline \multirow[t]{2}{*}{9} & \multirow[t]{2}{*}{ High morality } & intelligence & 78 & 16 & 4 & 47 & $59.77 * *$ & .797 & Bias \\
\hline & & morality & 79 & 13 & 6 & 46 & $62.73 * *$ & .836 & Accurate \\
\hline \multirow[t]{2}{*}{4} & \multirow[t]{2}{*}{ Low morality } & intelligence & 66 & 24 & 8 & 45 & $9.34 * *$ & .322 & Bias \\
\hline & & morality & 53 & 31 & 14 & 42 & 2.62 & .177 & $\begin{array}{l}\text { No } \\
\text { Accurate }\end{array}$ \\
\hline \multirow[t]{2}{*}{6} & \multirow[t]{2}{*}{ Low morality } & intelligence & 56 & 27 & 15 & 41.5 & $4.72 *$ & .238 & Bias \\
\hline & & morality & 28 & 64 & 6 & 46 & $6.65 * *$ & .269 & Accurate \\
\hline
\end{tabular}

Note: Expected frequencies according to chance were calculated according to this formula: (frequencies of right choice + frequencies of wrong choice) $\div 2 ; \dagger$ "I don't know her" or "she is familiar for me"; **: $\mathrm{p}<0.01 ; *$ : $p>0.05$; $\dagger \dagger$ to calculate Cohen's W the "other choices" were not considered in N

Frequencies of in/accurate choices and the results of $\chi^{2}$ statistical tests for intelligence and morality collectively, separately for any of the 4 conditions, for added low and high cases (whether morality/intelligence) and for composite accuracy of all targets are displayed in Table 2. As it shows, there are above-than-chance $(\mathrm{p}<0.01)$ accurate judgments of combined intelligence targets, combined high intelligence targets, combined high targets and also the composite of all targets. However, there were not above-than-chance accuracies at the combined morality targets, low or high morality targets or low intelligence and combined lows targets. Following Cohen (1988), the effect size for accurate 
perception of high intelligent targets was found to be moderate $(0.3<\mathrm{W}<0.5)$ and other effect sizes were small $(0.1<\mathrm{W}<0.3)$.

Table 2. The combined in/accurate judgments for the four conditions (low/high morality and low/high intelligence)

\begin{tabular}{|c|c|c|c|c|c|c|}
\hline Group & $\begin{array}{l}\text { Right } \\
\text { (Frequencies) }\end{array}$ & $\begin{array}{l}\text { Wrong } \\
\text { (Frequencies) }\end{array}$ & $\begin{array}{l}\text { Other } \\
\text { choices } \dagger \\
\text { (Frequencies) }\end{array}$ & $\begin{array}{l}\text { Expectations according to } \\
\text { chance (Frequencies) }\end{array}$ & $\chi^{2}$ & $\begin{array}{lr}\text { Effect } & \text { size } \\
\text { (Cohen's } & \text { W) } \\
\dagger \dagger & \end{array}$ \\
\hline Intelligence & 226 & 122 & 44 & 174 & $15.24 * *$ & .209 \\
\hline Morality & 192 & 166 & 34 & 179 & .87 & .049 \\
\hline $\begin{array}{l}\text { High } \\
\text { intelligence }\end{array}$ & 136 & 40 & 20 & 88 & $25.64 * *$ & .382 \\
\hline $\begin{array}{l}\text { Low } \\
\text { intelligence }\end{array}$ & 90 & 82 & 24 & 86 & .14 & .001 \\
\hline $\begin{array}{l}\text { High } \\
\text { morality }\end{array}$ & 97 & 85 & 14 & 91 & .33 & .042 \\
\hline low morality & 95 & 81 & 20 & 88 & 0.48 & .052 \\
\hline Highs & 233 & 125 & 34 & 179 & $15.99 * *$ & .211 \\
\hline Lowes & 185 & 163 & 44 & 174 & .63 & .002 \\
\hline Overall & 418 & 288 & 78 & 353 & $11.78 * *$ & .129 \\
\hline
\end{tabular}

Note: Expected frequencies according to chance were calculated according to this formula: (frequencies of right choice + frequencies of wrong choice) $\div 2$; † "I don't know" or "I know her"; **: $p<0.01 ; *$ : $p>0.05$; †† to calculate Cohen's W the "other choices" were not considered in $\mathrm{N}$

\section{2-3. Discussion}

The findings were not much perspicuous and besides accurate perceptions, there were many inaccurate biases in social perception of the targets. Considering combined accuracies (Table 2) and considering the judgments about each individual target (Table 1), it seems that the true judgments probably did not completely indicate the accurate social perception but it may be somewhat explained by the possible bias to judge the targets positively. Indeed, viewing the judgments of each target shows that except the average target and both the low intelligent targets, the participants had considered all the other six targets as highly intelligent (4 of them were targets with high or low morality while average in intelligence).Also, except one target with high morality and both targets with low morality levels, the participants had considered all the other six targets as highly moral (five of them were the targets with average, high or low intelligence while with an average morality level). Perhaps, it can be said that the approximately general positive illusion, somewhat, led to the pseudo-accurate perception at judgments about targets with high morality and high intelligence. Combined accuracies (Table 2) show that combined highs had more-than-chance accuracies but combined lows did not have it.

However, positive bias cannot completely explain the findings; there was one target that was accurately and negatively judged at morality and also there was the average target that was inaccurately and negatively judged at intelligence. In addition, although many targets were considered more-than-chance 
as high in intelligence (Table 1), at-chance-level perception was observed about lowly intelligent targets. Perhaps, it can be said that positive bias to judge others as intelligent, were thwarted in the targets with genuine low intelligence; however, not to the extent that they could be considered significantly lowly intelligent. In the same way, the positive bias to judge others as highly moral was thwarted in the targets with low morality; in a case, even the accurate negative judgment was found to be significant. Also, in combined accuracies (Table 2), that accuracies of the positive and negative targets were added and the accuracy is higher than the positive bias, there were more accurate judgments than inaccurate ones in combined intelligence (added highs/lows) and overall judgments. However, in both cases, the effect sizes were small;for the combined judgment, the Cohen's W was.129 and for the combined intelligent target, it was .209.It seems that particularly about intelligence, there are some traces of accurate social perceptions among the evidences of biases and inaccuracies. The trace of accuracies in the perception of intelligence is somewhat in accordance with some previous studies (Borkenau \& Liebler, 1993; Murphy et al., 2003; Zebrowitz \& Rhodes, 2004; Murphy, 2007; Rule et al., 2013).

Some studies have confirmed the accurate perception of some variables that are conceptually near to morality, such as aggression (Berry, 1990), warmth and honesty (Borkenau \& Liebler, 1993) and conscientiousness (Burgoon \& Le Poire, 1999) in zero information condition. In the current study, a target with low morality and a target with high morality were judged correctly (Table 2). Whereas accuracies in perception of total intelligence, judgment about total morality, low morality and high morality were not more-than-chance (Table 2); this is according to the findings of Rule et al., (2013) who studied moral behaviors as subject of perception.

Accurately or inaccurately, in many choices (14 from 18 choices), the students judged the targets abovethan-chance; even in the average cases (the average targets and the targets who were average in intelligence but different in morality and vice versa) that expectations were at-chance-level selection. Such tendencies were congruent with previous studies (Wojciszke et al., 1998; De Bruin, \& Van Lange, 1999; Wojciszke, 2005) which consider morality and intelligence (warmth-competence) as the underlying components of social perception. Indeed, the findings of the present study have indicated that individuals as targets of social perception emit the cues that were perceived by others even wrongly as the cues of high/low morality and intelligence.

\section{Study 2}

Study 1 has shown that in zero acquaintance condition, social perception of morality and intelligence is full of positive biases; however, with some traces of accuracies. But what is the origin of such biases? It was presumed that social perception in zero acquaintance condition feels direct, unmediated and is not propositional. Butanother way of social perception was to propositionally reason about how the mind 
operates (Lieberman, 2007).Such reasoning is similar to people's implicit or even automatic social cognition (Jussim, 2005) or Implicit Theories of Personality (Dweck, Chiu \& Hong, 1995).

High correlation between perceptions of a trait and another can be one of the sources of biases (Todorovet al., 2008). One of indications of individuals' implicit theories of personality is which traits converge in the individuals' expectations (Baron et al., 2006). Perhaps people's belief about how the morality or intelligence works results in such a bias and mistaken perceptions. If participants generally have Machiavellian attitude (Hunter, Gerbing \& Boster, 1982) in their implicit theories of personality, when they consider others highly moral, they would consider them lowly intelligent and vice versa; on the other hand, the negative relationship between other's perception as moral and intelligent would be predicted. But if people in their implicit theories of personality have positive ideas about human nature or the perspective of Unity of the Virtues such as Socrates and Plato (Wolf, 2007), they have to consider moral people as intelligent and vice versa, then their perceptions of morality is positively related to their perceptions of intelligence. Study 2 was designed to validate the findings of study 1; In addition, the relationship between the perception of morality and intelligence perception was studied. In this study, the targets were the same; however, the participants and the checklist were somewhat different. The checklist had an interval scale; so, it made it possible to have more parametric statistical analysis.

\section{3-1. Method}

\section{3-1-1. Checklist}

The checklist was the same as study 1 , but in a Likert scale from -5 to +5 . When participants perceived a target as average or when they could not judge about her, the item could be scored 0 . Similar to study 1, when any of participants announced that a target was familiar to her/him, the item of the target was omitted in the analysis.

\section{3-1-2. Participants}

96 undergraduate university students from Salman Farsi University of Kazerun, Iran (70 females, mean of age: $21.29 ; \mathrm{SD}=1.58$ ) participated in the study as the judges. Similar to study 1 , they were selected through convenient sampling and participation in the study was absolutely voluntary.

\section{3-1-3. Data analysis}

One-sample t-test was used to examine above-than-chance accurate or inaccurate selections for any target. The amount of combined accuracy was calculated by reversing the scores of low (morality/intelligence) targets; hence, negative scores represent inaccurate judgment and positive scores represent accurate judgment. The scores of combined accuracies were added for all of the four conditions (high morality, low morality, high intelligence and low intelligence), for the variables of morality and intelligence, low and high conditions (whether morality/intelligence) and for overall. Paired-sample t- 
test was used to compare the accuracies of judges' perceptions of morality and intelligence and of highs and lows conditions. In addition, the relation between judging target's morality and judging target's intelligence was analyzed by Pearson correlation coefficients.

\section{3-2. Findings}

Table 3 represents above-than-chance perceptions about each target in morality, intelligence and their correspondence with study 1 . For many targets, there are significant t-value in accurate or inaccurate (biases) perceptions. As table 3 represents, only three out of 18 judgments were incongruent to study1.Table 4 represents the above-than-chance of the collected accuracy scores and their agreement with study 1 . There were incongruities between the findings of this part and study 1 in the case of high morality, combined morality and combined lows. High morality and combined morality became accurate but combined lows became inaccurate. The effect sizes of accuracy (Cohen's d) for combined intelligence (.275), combined morality (.171) and combined judgments $(.221)$ were small $(0.2<\mathrm{d}<0.5)$ (see Cohen, 1988). Table 5 shows the relationships between judging the targets as being moral and intelligent. As the table represents, except for one target, there were significantly positive correlations between them. The amount of significant correlation coefficients as effect sizes include medium $(0.3<$ $r<0.5)$ and large ( $r>.5)$ effect sizes (see Cohen, 1988).

Table 3. Above-than-chance scores of judgments for any targets

\begin{tabular}{|c|c|c|c|c|c|c|c|c|}
\hline $\begin{array}{l}\text { Targets' } \\
\text { Number } \\
\text { (Targets' } \\
\text { Order) }\end{array}$ & $\begin{array}{l}\text { Actual traits } \\
\text { of target }\end{array}$ & $\begin{array}{l}\text { Judgment as } \\
\ldots .\end{array}$ & Mean & SD & $\mathrm{t}$ & $\begin{array}{l}\text { Effect } \\
\text { size(Cohen's d) }\end{array}$ & $\begin{array}{l}\text { Accuracy } \\
\text { or Bias }\end{array}$ & $\begin{array}{l}\text { Congruency to } \\
\text { study } 1\end{array}$ \\
\hline \multirow[t]{2}{*}{1} & \multirow[t]{2}{*}{ Average case } & intelligence & 0 & 1.61 & .000 & 0 & Accurate & No \\
\hline & & morality & 1.48 & 1.61 & $8.98 * *$ & .919 & Bias & Yes \\
\hline \multirow[t]{2}{*}{5} & \multirow{2}{*}{$\begin{array}{l}\text { High } \\
\text { intelligence }\end{array}$} & intelligence & .88 & 1.67 & $5.16^{* *}$ & .527 & Accurate & Yes \\
\hline & & morality & 1.17 & 1.63 & $6.99 * *$ & .718 & Bias & Yes \\
\hline \multirow[t]{2}{*}{7} & \multirow{2}{*}{$\begin{array}{l}\text { High } \\
\text { intelligence }\end{array}$} & intelligence & 1.37 & 1.54 & $8.72 * *$ & .89 & Accurate & Yes \\
\hline & & morality & 1.69 & 1.49 & $11.10 * *$ & 1.134 & Bias & Yes \\
\hline \multirow[t]{2}{*}{3} & \multirow[t]{2}{*}{$\begin{array}{l}\text { Low } \\
\text { intelligence }\end{array}$} & intelligence & .31 & 1.77 & 1.69 & .175 & $\begin{array}{l}\text { No } \\
\text { Accurate }\end{array}$ & Yes \\
\hline & & morality & 1.8 & 1.86 & $9.38 * *$ & .968 & Bias & Yes \\
\hline \multirow[t]{2}{*}{8} & $\begin{array}{l}\text { Low } \\
\text { intelligence }\end{array}$ & intelligence & .29 & 1.66 & 1.73 & .175 & $\begin{array}{l}\text { No } \\
\text { Accurate }\end{array}$ & Yes \\
\hline & & morality & .81 & 1.67 & $4.73 * *$ & .485 & Bias & Yes \\
\hline \multirow[t]{2}{*}{2} & High morality & intelligence & .92 & 1.34 & $6.69 * *$ & .687 & Bias & Yes \\
\hline & & morality & .02 & 2.13 & .1 & .009 & $\begin{array}{l}\text { No } \\
\text { Accurate }\end{array}$ & Yes \\
\hline \multirow[t]{2}{*}{9} & High morality & intelligence & 1.02 & 1.7 & $5.89 * *$ & .6 & Bias & Yes \\
\hline & & morality & 1.14 & 1.69 & $6.55 * *$ & .67 & Accurate & Yes \\
\hline \multirow[t]{2}{*}{4} & \multirow[t]{2}{*}{ Low morality } & intelligence & -1.05 & 1.81 & $-5.68 * *$ & .801 & Bias & No \\
\hline & & morality & .12 & 1.85 & .61 & .06 & $\begin{array}{l}\text { No } \\
\text { Accurate }\end{array}$ & Yes \\
\hline \multirow[t]{2}{*}{6} & Low morality & intelligence & .91 & 1.58 & $5.61 * *$ & .576 & Bias & Yes \\
\hline & & morality & .19 & 1.63 & 1.14 & .117 & $\begin{array}{l}\text { No } \\
\text { Accurate }\end{array}$ & No \\
\hline
\end{tabular}

$* *: \mathrm{p}<0.01 ; *: \mathrm{p}>0.05$ 
Table 4. Above-than-chance accuracies of judgments for any conditions

\begin{tabular}{|l|l|l|l|l|l|l|l|}
\hline Group & $\begin{array}{l}\mathrm{N} \text { (of any } \\
\text { choices) }\end{array}$ & Mean & SD & $\mathrm{t}$ & $\begin{array}{l}\text { Effect size (Cohen's } \\
\mathrm{d})\end{array}$ & Accuracy & $\begin{array}{l}\text { Congruency to study } \\
1\end{array}$ \\
\hline Intelligence & 188 & .86 & 3.13 & $3.75^{* *}$ & .275 & Yes & Yes \\
\hline Morality & 188 & .46 & 2.69 & $2.33^{*}$ & .171 & Yes & No \\
\hline $\begin{array}{l}\text { High } \\
\text { intelligence }\end{array}$ & 95 & 2.25 & 2.77 & $7.93^{* *}$ & .812 & Yes & Yes \\
\hline $\begin{array}{l}\text { Low } \\
\text { intelligence }\end{array}$ & 93 & -.57 & 2.83 & -1.94 & .201 & No & Yes \\
\hline High morality & 94 & 1.81 & 2.71 & $4.22^{* *}$ & .668 & Yes & No \\
\hline low morality & 94 & -.27 & 2.48 & -1.04 & .109 & No & Yes \\
\hline Highs & 188 & 1.69 & 2.75 & $8.39^{* *}$ & .614 & Yes & Yes \\
\hline Lowes & 187 & -.42 & 3.65 & $-2.15^{*}$ & .115 & No & No \\
\hline Overall & 375 & .64 & 2.9 & $4.26^{* *}$ & .221 & Yes & Yes \\
\hline
\end{tabular}

Note: negative mean represents inaccurate perception; $* *: p<0.01 ; *: p>0.05$

Table 5. The relationships between judging the targets as moral and intelligent

\begin{tabular}{|l|l|l|l|l|l|}
\hline $\begin{array}{l}\text { Targets' } \\
\text { Number } \\
\text { Targets } \\
\text { order })\end{array}$ & $\begin{array}{l}\text { Actual traits of } \\
\text { target }\end{array}$ & $\begin{array}{l}\text { Correlations of judges it as } \\
\text { intelligent or moral }\end{array}$ & $\begin{array}{l}\text { Targets' } \\
\text { Number } \\
\text { (Targets } \\
\text { order) }\end{array}$ & $\begin{array}{l}\text { Actual traits } \\
\text { of target }\end{array}$ & $\begin{array}{l}\text { Correlations of judges it as } \\
\text { intelligent or moral }\end{array}$ \\
\hline 1 & Average case & $.24^{*}$ & 2 & $\begin{array}{l}\text { High } \\
\text { morality }\end{array}$ & $.29^{* *}$ \\
\hline 5 & $\begin{array}{l}\text { High } \\
\text { intelligence }\end{array}$ & $.32^{* *}$ & 9 & $\begin{array}{l}\text { High } \\
\text { morality }\end{array}$ & $.57^{* *}$ \\
\hline 7 & $\begin{array}{l}\text { High } \\
\text { intelligence }\end{array}$ & $.46^{* *}$ & 4 & Low morality & .17 \\
\hline 3 & $\begin{array}{l}\text { Low } \\
\text { intelligence }\end{array}$ & $.26^{* *}$ & 6 & Low morality & $.39 * *$ \\
\hline 8 & $\begin{array}{l}\text { Low } \\
\text { intelligence }\end{array}$ & $.44^{* *}$ & & & \\
\hline$* * p<0.01$ & & & & &
\end{tabular}

\section{3-3. Discussion}

The findings of study 1 are to some extent repeated in study 2. From 18 judgments, 14 were the same as the judgments found in study 1 (Table 3). Through 18 judgments, only five of them were at-chancelevel (one of them was for average target then became accurate). Other judgments showed above-thanchance accurate and above-than-chance biased or inaccurate perception. The findings generally confirm the conclusion of study 1 , in that there is no neutral orientation to targets with regard to morality and intelligence (Wojciszke et al., 1998; Wojciszke, 2005) even in the form of the biases. The approximately same attribution of morality and intelligence to the targets in study 1 and 2 shows that some individuals repeatedly and inaccurately or sometimes accurately show themselves high or low in intelligence/morality. In the case of morality, such consensus is in agreement with Rule et al. (2013). 
Although it was found that three of morally different targets were perceived at-chance-level, incongruent to study 1 , combined accuracies were found in morality, and high moral cases. Then, it can be said that applying interval scale in this study resulted in higher accuracies in morality perception. However, congruent to study 1 the effect size is small.

The obtained combined accuracies showed that there is a significantly inaccurate judgment about low condition targets (morality, intelligence and combined lows), but there are accurate judgments about high condition targets (morality, intelligence and combined highs) (Tables 4). This is in agreement with the conclusion of study 1 , in that instead of considering accuracies for the students' judgments about their peer targets, it can be said that there was a positive bias to attribute them morality and intelligence; That bias is showed as some sorts of pseudo accuracies in the positive and high conditions.

In study 1 , the accuracies of combined overall judgment and combined judgment of intelligence and also one of lowly moral targets permitted to consider traces of accuracies beyond positive bias. However, in study 2, any low targets and combined low intelligence, and combined low morality did not have significant accuracies and even combined lows had significant inaccuracy. But combined judgment of morality, intelligence and also overall judgment have above-than-chance accuracies. Then, it can be possibly discussed that among the inaccurate judgments made, there are still some traces of accuracy beyond positive biases. The traces that are in accordance with some previous studies about evidences of accurate perception of intelligence (Borkenau \& Liebler, 1993; Murphy et al., 2003; Zebrowitz \& Rhodes, 2004; Murphy, 2007; Rule et al., 2013) and accurate perception of the variables that were conceptually near to morality (Berry, 1990; Borkenau \& Liebler, 1993; Burgoon \& Le Poire, 1999). But this little evidence of accurate perception of morality is not congruent to the study of Rule et al. (2013). In that study photos were used as stimuli but in present study movies were used. Movies that were used in this study probably have more cues for tracing morality.

The positive relationships between considering targets intelligent and considering them as highly moral (Table 7) support the existence of optimistic account to human nature, as an implicit theory of personality, at least among the student participants. According to this implicit theory, moral people are intelligent and vice versa; the view such as Socrates and Plato's idea of unity of the virtues (Wolf, 2007). In fact, this positive relationship showed that the participants did not have a negative or Machiavellian (Hunteret al., 1982) view toward human nature and morality; the view that implies that intelligent people would not be moral. Perhaps the optimistic view of the participants can be attributed to the idealistic view of Students' age; then doing the study among different population (age, generation, job, and social class) might lead to different correlations and then would allude to different implicit theories of 
personality. Optimistic or pessimistic, it can be concluded that implicit theory to human nature can lead to biases and misperceptions of people as high or low in morality or intelligence.

\section{4- Study 3}

In many genuine minimal acquaintance conditions that people judge others' characteristics, such as employment interviews (Morgeson \& Campion, 1997; Garcíaet al., 2008; De Groot \& Gooty, 2009; Schmid Mast et al., 2011), judgment was made after group discussions and judges consider themselves as specialist in realizing other's personality. It was presumed that educated people in social science (such as psychology) can more accurately judge about others. However, the idea was rarely tested (Jussim, 2005). In a study, Powell and Goffin (2009) could not enhance the accuracies of some interviewers after training a protocol to enhance personality-related cues. In study 1 and study 2 , the average participants individually judged the targets. Perhaps using educated participants in the diagnosis of verbal and nonverbal cues could improve the accuracies.

In addition, perhaps having some discussions in a group by such individuals can affect their decision making and increase accuracies. However, despite the current social decision schemes of better judgments in group decision making (Davis, 1973), there are some processes such as conformity (Claidière \& Whiten, 2012), group thinking (Benabou, 2013; Park, 1990) or group polarization (Yardi, \& Boyd, 2010; Sunstein, 2002) that can affect the accurate judgments negatively. The aim of study 3 is studying the accuracies of social perception about the stranger's intelligence and moral identity after group debate among relatively educated participants in diagnosis of verbal and nonverbal cues.

\section{4-1. Method}

Targets and the checklist were similar to study 2. The participants were 14 Iranian students, studying at Salman Farsi University of Kazerun (13 of them were female, Mean of age: 24.46, SD: 3.15). Five of them were senior undergraduate students of psychology who had passed the courses such as personality psychology, social psychology, psychopathology, moral psychology and so forth. Nine of them were senior postgraduate students who had passed diagnosis interview debates across their psychopathology course and similar debate about nonverbal and verbal cues across their social psychology course. They were at a classroom and after watching every clip, they had10-minute time to discuss about the targets. Then, they completed the checklist individually. Similar to study 1 and 2, participation in the study was absolutely voluntary. Data analysis was the same as study 2 with the difference that due to the low sample size, the correlations were not calculated.

\section{4-2. Finding}

Table 6 represents the above-than-chance scores of judgment for each target by one sample t-test and their congruency to study 1 and 2 . As the table represents, only five out of 18 judgments were 
incongruent to study 1 and 4 of them to study 2 . In comparison to study 1 , three judgments became inaccurate or biased and two judgments become accurate. In comparison to study 2 , two judgments become accurate and two judgments become inaccurate or biased.

Table 6. Above-than-chance accuracies of judgment for any conditions

\begin{tabular}{|c|c|c|c|c|c|c|c|c|c|}
\hline $\begin{array}{l}\text { Targets' } \\
\text { Number } \\
\text { (Targets } \\
\text { ' Order) }\end{array}$ & $\begin{array}{l}\text { Actual } \\
\text { traits of } \\
\text { target }\end{array}$ & $\begin{array}{l}\text { Judgment } \\
\text { as .... }\end{array}$ & Mean & SD & $\mathrm{T}$ & $\begin{array}{l}\text { Effect } \\
\text { size } \\
\text { (Cohen' } \\
\text { s d) }\end{array}$ & $\begin{array}{l}\text { Accurac } \\
\text { y or Bias }\end{array}$ & $\begin{array}{l}\text { Congruenc } \\
\text { y to study } 1\end{array}$ & $\begin{array}{l}\text { Congruenc } \\
\text { y to study } 2\end{array}$ \\
\hline \multirow[t]{2}{*}{1} & $\begin{array}{l}\text { Average } \\
\text { case }\end{array}$ & $\begin{array}{l}\text { intelligenc } \\
\mathrm{e}\end{array}$ & $\begin{array}{l}- \\
.07 \\
1\end{array}$ & .83 & -.32 & .085 & Accurate & No & Yes \\
\hline & & morality & $\begin{array}{l}3.6 \\
4\end{array}$ & .5 & $\begin{array}{l}27.41 * \\
*\end{array}$ & 7.28 & Bias & Yes & Yes \\
\hline \multirow[t]{2}{*}{5} & \multirow{2}{*}{$\begin{array}{l}\text { High } \\
\text { intelligenc } \\
\mathrm{e}\end{array}$} & $\begin{array}{l}\text { intelligenc } \\
\mathrm{e}\end{array}$ & .14 & $\begin{array}{l}1.5 \\
6\end{array}$ & .34 & .09 & $\begin{array}{l}\text { No } \\
\text { Accurate }\end{array}$ & No & No \\
\hline & & morality & $\begin{array}{l}1.9 \\
3 \\
\end{array}$ & $\begin{array}{l}1.2 \\
1\end{array}$ & $5.98 * *$ & 1.595 & Bias & Yes & Yes \\
\hline \multirow[t]{2}{*}{7} & \multirow{2}{*}{$\begin{array}{l}\text { High } \\
\text { intelligenc } \\
\mathrm{e}\end{array}$} & $\begin{array}{l}\text { intelligenc } \\
\mathrm{e}\end{array}$ & $\begin{array}{l}2.7 \\
1\end{array}$ & $\begin{array}{l}1.3 \\
3\end{array}$ & $7.66^{* *}$ & 2.038 & Accurate & Yes & Yes \\
\hline & & morality & 3.5 & .85 & $\begin{array}{l}15.33 * \\
*\end{array}$ & 4.118 & Bias & Yes & Yes \\
\hline \multirow[t]{2}{*}{3} & \multirow{2}{*}{$\begin{array}{l}\text { Low } \\
\text { intelligenc } \\
\mathrm{e}\end{array}$} & $\begin{array}{l}\text { intelligenc } \\
\mathrm{e}\end{array}$ & .29 & $\begin{array}{l}1.6 \\
8\end{array}$ & .63 & .173 & $\begin{array}{l}\text { No } \\
\text { Accurate }\end{array}$ & Yes & Yes \\
\hline & & morality & $\begin{array}{l}3.3 \\
6 \\
\end{array}$ & $\begin{array}{l}1.6 \\
9\end{array}$ & $7.42 * *$ & 1.988 & Bias & Yes & Yes \\
\hline \multirow[t]{2}{*}{8} & \multirow{2}{*}{$\begin{array}{l}\text { Low } \\
\text { intelligenc } \\
\mathrm{e}\end{array}$} & $\begin{array}{l}\text { intelligenc } \\
\mathrm{e}\end{array}$ & -.27 & $\begin{array}{l}1.0 \\
1 \\
\end{array}$ & -.9 & .267 & $\begin{array}{l}\text { No } \\
\text { Accurate }\end{array}$ & Yes & Yes \\
\hline & & morality & .73 & $\begin{array}{l}1.8 \\
5\end{array}$ & 1.30 & .395 & Accurate & No & No \\
\hline \multirow[t]{2}{*}{2} & \multirow[t]{2}{*}{$\begin{array}{l}\text { High } \\
\text { morality }\end{array}$} & $\begin{array}{l}\text { intelligenc } \\
\mathrm{e}\end{array}$ & .71 & $\begin{array}{l}1.2 \\
0\end{array}$ & $2.22 *$ & .592 & Bias & Yes & Yes \\
\hline & & morality & -.36 & 1.5 & -.9 & .24 & $\begin{array}{l}\text { No } \\
\text { Accurate }\end{array}$ & Yes & Yes \\
\hline \multirow[t]{2}{*}{9} & \multirow[t]{2}{*}{$\begin{array}{l}\text { High } \\
\text { morality }\end{array}$} & $\begin{array}{l}\text { intelligenc } \\
\mathrm{e}\end{array}$ & $\begin{array}{l}1.9 \\
3 \\
\end{array}$ & $\begin{array}{l}1.4 \\
4\end{array}$ & $5.01 * *$ & 1.34 & Bias & Yes & Yes \\
\hline & & morality & $\begin{array}{l}3.4 \\
3\end{array}$ & $\begin{array}{l}1.1 \\
6\end{array}$ & $\begin{array}{l}11.08^{*} \\
*\end{array}$ & 2.957 & Accurate & Yes & Yes \\
\hline \multirow[t]{2}{*}{4} & \multirow[t]{2}{*}{$\begin{array}{l}\text { Low } \\
\text { morality }\end{array}$} & $\begin{array}{l}\text { intelligenc } \\
\mathrm{e}\end{array}$ & $\begin{array}{l}- \\
1.0 \\
7\end{array}$ & $\begin{array}{l}1.4 \\
4\end{array}$ & $-2.78 * *$ & .743 & Bias & No & Yes \\
\hline & & morality & .93 & $\begin{array}{l}1.6 \\
4\end{array}$ & $2.12^{\sim}$ & .567 & Bias† & No & No \\
\hline \multirow[t]{2}{*}{6} & \multirow[t]{2}{*}{$\begin{array}{l}\text { Low } \\
\text { morality }\end{array}$} & $\begin{array}{l}\text { intelligenc } \\
\mathrm{e}\end{array}$ & 2 & $\begin{array}{l}1.1 \\
8\end{array}$ & $6.36^{* *}$ & 1.695 & Bias & Yes & Yes \\
\hline & & morality & -.71 & $\begin{array}{l}1.4 \\
4\end{array}$ & $-1.86^{\sim}$ & .493 & Accurate & Yes & No \\
\hline
\end{tabular}

$* *: p<0.01 ; *: p>0.05 ; \sim: p>0.1$

Table 7 represents the combined accuracy scores and congruency of their significances to study 1 and 2. As the table represents, more-than-chance accuracies of intelligence, high intelligence, highs, overall 
judgments and also at-chance-level judgments of low intelligence levels, were repeated in all of the three studies. But the study is incongruent to both previous studies, showing significant inaccurate perception of targets with low morality; also contrary to study 1, this study showed the accurate judgment of high morality and contrary to study 2 , it showed the inaccurate judgment of combined morality. Also similar to study 1 , the study represented accurate judgment of high morality and inaccurate judgment of overall lows. The effect sizes (Cohen's d) for overall accuracies in perception of intelligence (.764) and in all overall judgments $(.606)$ were moderate $(0.5<\mathrm{d}<0.8)$ (see Cohen, 1988).

Table 7. Above-than-chance accuracies of judgments for all conditions

\begin{tabular}{|l|l|l|l|l|l|l|l|l|}
\hline group & $\begin{array}{l}\text { N (of any } \\
\text { choices) }\end{array}$ & Mean & SD & t & $\begin{array}{l}\text { Effect } \\
\text { size(Cohen's d) }\end{array}$ & accuracy & $\begin{array}{l}\text { Congruency to } \\
\text { study 1 }\end{array}$ & $\begin{array}{l}\text { Congruency to } \\
\text { study } 2\end{array}$ \\
\hline Intelligence & 25 & 1.72 & 2.25 & $3.82^{* *}$ & .764 & Yes & Yes & Yes \\
\hline Morality & 27 & .70 & 3.39 & 1.08 & .206 & No & Yes & No \\
\hline $\begin{array}{l}\text { High } \\
\text { intelligence }\end{array}$ & 14 & 2.86 & 1.78 & $6.12^{* *}$ & 1.607 & Yes & Yes & Yes \\
\hline $\begin{array}{l}\text { Low } \\
\text { intelligence }\end{array}$ & 11 & .27 & 2 & .45 & .135 & No & Yes & Yes \\
\hline $\begin{array}{l}\text { High } \\
\text { morality }\end{array}$ & 14 & 3.07 & 2.12 & $5.4^{* *}$ & 1.448 & Yes & No & Yes \\
\hline low morality & 14 & -1.79 & 2.45 & $-2.72^{*}$ & .731 & No & No $\dagger$ & No $\dagger$ \\
\hline Highs & 27 & 3.07 & 1.86 & $8.59^{* *}$ & 1.65 & Yes & Yes & Yes \\
\hline Lowes & 25 & -.88 & 2.45 & $-1.79^{*}$ & .359 & No & No $\dagger$ & Yes \\
\hline Overall & 52 & 1.17 & 1.93 & $2.89^{* *}$ & .606 & Yes & Yes & Yes \\
\hline
\end{tabular}

**: $\mathrm{p}<0.01 ; *: \mathrm{p}>0.05 ; \sim \mathrm{p}>0.1 ; \dagger$ they were inaccurate but no statistically significant

\section{4-3. Discussion}

The findings of study 3 showed similarities to study 2 and then to study 1 (see Tables 6 and7). However, contrary to study 2 , the judgment of combined accuracy of morality was not more than chance and the combined judgment of low morality was inaccurately and significantly positive. Then, in the case of morality, the accuracies (of high morality) could not be beyond positive biases.

Informational conformity usually occurs in uncertain situations (Claidière \& Whiten, 2012). Perhaps morality cues are less tangible than intelligence cues (Rule et al., 2013), then conformity from others in group discussions has been more achieved in judgment about morality and hence it led to a deviation from accuracies in group conditions. Conformity and other processes such as group polarization (Yardi, \& Boyd, 2010, Sunstein, 2002) or group thinking (Benabou, 2013; Park, 1990) may have led to such more inaccurate judgments of this study in comparison to study 1 and 2.

Relatively congruence to Powell and Goffin's (2009) findings and despite the expectation of enhancing accuracy, the group discussions of relatively educated students could not increase accuracies and 
decrease inaccuracies. There were not considerable changes in perception of intelligence but in the case of morality, there were increased positive biased judgments. Significant but inaccurate perceptions of some of the targets were repeated in this study. This shows that judging others after a group discussion with educated ones in minimal acquaintance condition could not prevent the prejudice that might be originated from the things such as appearance, clothes, or accent of others.

\section{5- General discussions and Conclusions}

The present studies aimed to examine the accuracies of perception of morality and intelligence as the underlying components of social perception (Wojciszke et al., 1998; De Bruin \& Van Lange, 1999; Wojciszke, 2005) in zero acquaintance condition. Many false and inaccurate perceptions in the findings indicate that the intuitive perception of others without adequate information could not lead to reliable judgments. According to the finding of study 3, even in collective debate and by educated judges, such false perceptions could not be modified (see Powell \& Goffin, 2009) and even it would be increased.

The findings have shown that many targets, either correctly or incorrectly were perceived significantly highly/lowly moral or intelligent. It shows that people are not neutral in their perceptions of other's morality and intelligence. Many of such significant perceptions were repeated in all three studies. In the same vein, Rule et al., (2013) in the case of morality (trustworthiness) have shown high consensus and no accuracy. There might be some reasons behind such repeated false or true perception, such as the verbal or nonverbal cues (Murphy et al., 2003; Murphy, 2007; Zebrowitz and Rhodes, 2004, Linkeet al., 2016) or the clothes (Mahmud and Swami, 2010) or attractiveness (Zebrowitz et al., 2007; Talamaset al., 2016) of the targets that led to judge's prejudice or judge's accurate perceptions.

A reason of some repeated false or true selections may be the positive orientation of the student participants to their peer targets. In all of the studies, participants more accurately judged targets with high morality/intelligence level than those with low levels. Then, it can be said that in the perception of highly moral and highly intelligent targets, there was not really original accurate perception and it is the outcome of positive bias. Such positive bias was more about morality than intelligence inasmuch as in study 3 , there was inaccurate positive perception about combined low moral targets.

There would be some other probabilities for such a positive bias. One of the causes of judges' orientations and especially not realizing the targets of low morality might be the gender of participants. All targets and most of judges were females. Despite the female's superiority in accurate realization of the nonverbal cues (Blanck et al., 1981; Murphy et al., 2003), there were evidences of the disadvantage in realizing cues of deception and lies (Baron et al., 2006); The disadvantage that may have affected their realization of targets with low morality. However, such explanation is not certain, because there was also the positive bias in realizing low intelligent people too. 
One of the other probabilities of the positive bias might be implicit theories of personality (Dwecket al., 1995) of the judges. One of the findings of study 2 was the positive correlations of judges' perceptions of morality and judges' perceptions of intelligence. In fact, when judges consider the targets as intelligent, they consider her generally as highly moral and vice versa. Perhaps implicit belief of the unity of the virtues (Wolf, 2007) led to such a bias. Moreover, using participants with different attitudes in future studies, such as Machiavellian attitude, might lead to some different results.

In spite of the fact that the findings were full of inaccuracies and bias, there were traces of accuracies beyond the positive bias, particularly in the intelligence cases. Despite general positive biases, there were some targets that were considered accurately or inaccurately low in all the studies. Also, the overall accuracies (added high and low cases) and combined accuracies in perception of intelligence were significant in all three studies. But combined accuracies in perception of morality were only significant in study 2 .

Considering morality as a trait is somewhat skeptical (Doris et al., 2020). Perhaps it can be said that the cues of morality are less tangible than intelligence (Rule et al., 2013) then according to Realistic Accuracy Model (Funder, 1995), it cannot be reliably perceived. But according to Ecological Model of Social Perception (McArthur \& Baron, 1983; Zebrowitz \& Collins, 1997), perception of other's morality is functionally more important than intelligence (Wojciszke et al., 1998; De Bruin \& Van Lange, 1999; Brambilla et al., 2011; Brambillaet al., 2012; Christyet al., 2017). Perhaps, it can be claimed that due to "negativity effects" phenomena in perception of morality (Martijn et al., 1998; Wojciszke et al., 1998 and Brambilla et al., 2011), having more optimistic view of other's morality in the first impression formation, is more informative; The positive perception that will be modified by "negativity effects" in the subsequent communications. Then, functionally more important accurate perception of morality than intelligence may show itself in more corrective interaction than in first impression formation and zero acquaintance conditions. Such claim can be examined in future studies.

This preliminary study has shown little traces of accurate and also repeated and perhaps rule-governed inaccurate perception of morality in zero acquaintance conditions. That can be considered as replication and validation of previous findings in an Iranian sample. There were some studies which have shown some accurate and inaccurate cues of perceiving the intelligence (Murphy et al., 2003; Murphy, 2007; Zebrowitz and Rhodes, 2004) and also morality (Linkeet al., 2016). Similar to their methodology, future studies can be conducted to validate the cues of accurate and inaccurate social perception of morality in zero acquaintance among Iranian or other non-western populations. To better understand, the study can be repeated by judges and targets with different attitudes, implicit theories of personality, ages, gender, social classes and etc. 
Present findings such as some previous studies confirm high consensus (Rule et al., 2013) and less accuracy in morality (Berry, 1990; Borkenau \& Liebler, 1993; Burgoon \& Le Poire, 1999; Zebrowitz \& Collins, 1997; Vogtet al., 2013) and intelligence (Borkenau \& Liebler, 1993; Murphyet al., 2003; Zebrowitz \& Rhodes, 2004; Murphy, 2007; Rule et al., 2013). In fact, congruent to the prediction of Realistic Accuracy Model (Funder, 1995), and the findings of previous studies (Jussim, 2005; Rule, et al., 2013), the effects sizes of accuracies beyond the positive effects in the present study were not large. These can be considered as an alarm to prevent from relying on intuitive perceptions especially about other's morality in situations such as employment interviews (Linkeet al., 2016) where making impression about others is critical.

Conflict of interest: Authors declare that they have no conflict of interest

Ethical approval: All procedures performed in studies involving human participants were in accordance with the ethical standards of the institutional and national research committee and with the 1964 Helsinki declaration and its later amendments or comparable ethical standards.

Informed consent: Informed consent was obtained from all individual participants included in the study.

Data availability statement: The datasets generated during the current study are available from the corresponding author on reasonable request.

\section{References}

Ambady, N., Bernieri, F. J., \&Richeson, J. A. (2000). Toward a histology of social behavior: Judgmental accuracy from thin slices of the behavioral stream. In M. P. Zanna (Ed.), Advances in experimental social psychology, 32, 201-271. San Diego, CA: Academic Press. http://dx.doi.org/10.1016/S00652601(00)80006-4

Aquino, K. \& Reed, A. (2002). The Self-Importance of Moral Identity. Journal of personality and social psychology,83(6), 1423-1440. http://doi.org/10.1037//0022-3514.83.6.1423

Aquino, K. Reed, A. Thau, S. \& Freeman, D. (2007). A grotesque and dark beauty: How moral identity and mechanisms of moral disengagement influence cognitive and emotional reactions to war. Journal of experimental social psychology, 43, 385-392. http://doi.org/10.1016/j.jesp.2006.05.013

Aquino, K., Freeman, D., Reed, A., Lim, V. K. G., \&Felps, W. (2009). Testing a social-cognitive model of moral behavior: The interactive influence of situations and moral identity centrality. Journal of personality and social psychology, 97, 123-141. http://doi.org/10.1037/a0015406

Azimpour, A. (2019). Moral-related Variables and Mental Health: A correlational Study. Iranian evolutionary and educational psychology Journal, 1(2).http://doi.org/10.21859/IEEPJ.1.2.135

Azimpour, A., Neasi A. Shehni-Yailagh M., Arshadi N., \& Beshlideh K. (2014). Validation the measure of "the self-importance of moral identity" on university students. Journal of Personality and individual differences (in Persian), 3(4), 19-38. 
Azimpour, A., Neasi A. Shehni-Yailagh, M., Arshadi, N., \& Beshlideh, K. (2012a). Designing and testing a model of important precedents of prosocial behavior in student of Shahid Chamran university of Ahvaz. Journal of psychological achievements (in Persian),19(3), 15-44.

Azimpour, A., Neasi A., Shehni-Yailagh M., \& Arshadi, N. (2012b). Validation of "Prosocial Tendencies Measure" in Iranian University Students. Journal of Life Science and Biomedicine, 2(2), 34-42.

Azimpour, A., Shehni-Yailagh, M., Esfandiyari, F., Abdollahi, S., \& Eslamiyeh, F.(2017). The relationship between Intelligence, prosocial moral reasoning and moral identity among the Iranian university students. IPA international journal of psychology, 11 (1), 151-181.

Baron, R. A., Byrne, D. E. \& Branscombe, N. R., (2006). Social psychology. Boston: Pearson/Allyn \& Bacon.

Baschetti, R. (2007). Evolutionary, neurobiological, gene-based solution of ideological "puzzle" of human altruism and cooperation. Medical hypotheses, 69(2), 241- 249. https://doi.org/10.1016/j.mehy.2007.03.020

Benabou, R. (2013). Groupthink: collective delusions in organizations and markets. Review of economic studies, 80, 429-462.http:// doi.org/10.1093/restud/rds030

Berry, D. S. (1990). Taking people at face value: Evidence for the kernel of truth hypothesis. Social Cognition, 8, 343-361. http://doi.org/10.1521/soco.1990.8.4.343

Blanck, P. D., Rosenthal, R., Snodgrass, S. E., DePaulo, B. M., \& Zuckerman, M. (1981). Sex differences in eavesdropping on nonverbal cues: developmental changes. Journal of personality and social psychology,41(2), 391-396. http://doi.org/10.1037/0022-3514.41.2.391

Borkenau, P. \&Liebler, A. (1993). Convergence of stranger ratings of personality and intelligence with self-ratings, partner ratings, and measured intelligence. Journal of Personality and Social Psychology,65(3), 546-553.http://doi.org/10.1037/0022-3514.65.3.546

Brambilla, M., Rusconi, P., Sacchi, S., \& Cherubini, P. (2011). Looking for honesty: The primary role of morality (vs. sociability and competence) in information gathering. European Journal of Social Psychology, 41(2), 135-143. doi:10.1002/ejsp.744

Brambilla, M., Sacchi, S., Rusconi, R., Cherubini, P., \&Yzerbyt, V. Y. (2012). You want to give a good impression? Be honest! Moral traits dominate group impression formation. British journal of social psychology, 51, 149-166. https://doi.org/10.1111/j.2044-8309.2010.02011.x

Burgoon, J. K. \& Le Poire, B. A. (1999). Nonverbal cues and interpersonal judgments: Participant and observer perceptions of intimacy, dominance, composure, and formality. Communication Monographs,66(2), 105-124.http://doi.org/10.1080/03637759909376467

Cattell R. B. \&Cattell A. K. S. (1973). Handbook for the Individual or Group Culture-Fair Intelligence Test: Scale 3. IPAT,Champaign, Ill.

Cattell, R. B. (1957). Culture fair intelligence test, a measure of " $\mathrm{g}$ ": Scale 3 forms A and B (high school pupils and adults of superior intelligence). Savoy, IL: Institute for Personality and Ability Testing.

Christy, A. G., Kim, J., Vess, M., Schlegel, R., J. \& Hicks, J. A. (2017). The reciprocal relationship between perceptions of moral goodness and knowledge of others' true selves. Social psychological and personality science, 8(8). 1-8. https://doi.org/ 10.1177/1948550617693061

Claidière, N. \& Whiten, A. (2012). Integrating the study of conformity and culture in humans and nonhuman animals. Psychological Bulletin, 138 (1).126-145. https://doi.org/I0.1037/a0025868

Cohen, J. (1988). Statistical power analysis for the behavioral sciences. Mahwah, NJ: Erlbaum.

Davis, J. H. (1973). Group decision and social interaction: A theory of socialdecision schemes. Psychological review, 80(2), 97-125.https://doi.org/10.1037/h0033951 
DeBruin, E. N. M., \& Van Lange, P. A. M. (1999). Impression formation and cooperativebehaviour. European Journal of Social Psychology, 29, 305 - 328. https://doi.org/10.1002/(SICI)10990992(199903/05)29:2/3<305::AID-EJSP929>3.0.CO;2-R

DeGroot, T., Gooty, J. (2009). Can nonverbal cues be used to make meaningful personality attribution in employment interviews? Journal of business and psychology, 24, 170-192. https://doi.org/101007/s10869-009-9098-0

Delgado, M. R., Frank, R. H., \& Phelps, E. A. (2005). Perception of moral character modulate the neural system of reward during the trust game. Nature neuroscience, 8 (11), 1611-1618. https://doi.org/10.1038/nn1575

Doris, J., Stich, S., Phillips, J. and Walmsley, L. (2020). Moral psychology: Empirical approaches. In E N. Zalta (Eds.), Stanford encyclopedia of philosophy. https://plato.stanford.edu/archives/spr2020/entries/moral-psych-emp/

Dweck, C S., Chiu, C, Hong, Y. (1995). Implicit theories and their role in judgments and reactions: A world from two perspectives. Psychological inquiry, 6, (4), 267-285. https://doi.org/ 10.1207/s15327965pli0604_1

Etcoff. N. L., Ekman. P., Magee, J. J., \& Frank, M. G. (2000). Lie detection and language comprehension; People who can't understand words are better at picking up lies about emotions. Nature, 405, 139-141. https://doi.org/10.1038/35012129

Fiske, S. T. (1993). Social cognition and social perception. In 1. W. Porter \& M. R. Rosenzwein (Eds.), Annual review of psychology, 44, 155- 194. https://doi.org/10.1146/annurev.ps.44.020193.001103

Funder, D. C. (1995). On the accuracy of personality judgment: A realistic approach. Psychological Review, 102, 652-670. http://dx.doi.org/10.1037/0033-295X.102.4.652

García, M. F., Posthuma, R. A. \& Colella, A. (2008). Fit perceptions in the employment interview: the role of similarity, liking, and expectations. Journal of occupational and organizational psychology, 81, 173-189. http:// doi.org/10.1348/096317907X238708

Grèzes, J., Frith, C. \& Passingham, R. E. (2004). Brain mechanisms for inferring deceit in the actions of others. The journal of neuroscience, 24(24), 5500 5505.https://doi.org/10.1523/JNEUROSCI.0219-04.2004

Hunter, J. H., Gerbing, D. W. \&Boster, F. J. (1982).Machiavellian beliefs and personality: Construct invalidity of the Machiavellianism dimension. Journal of personality and social psychology, 43 (6), 1293-1305 https://doi.org/ 10.1037/0022-3514.43.06.1293

Jussim, L. (1991). Social perception and social reality: A reflection-construction model. Psychological Review, 98, 54-73. https://doi.org/ 10.1037/0033-295X.98.1.54

Jussim, L. (2005). Accuracy in social perception: criticisms, controversies, critical, components, and cognitive processes. Advances in experimental social psychology, 37, 1-93. https://doi.org/10.1016/S0065-2601(05)37001-8

Kalat, J. W. (2007). Biological psychology. USA: Thompson learning, Inc.

Lieberman, M. D. (2007). Social cognitive neuroscience: A review of core processes. Annual Review of Psychology, 58, 259-89. https://doi.org/10.1146/annurev.psych.58.110405.085654

Linke, L., Saribay, S. A., \&Kleisner, K. (2016). Perceived trustworthiness is associated with position in a corporate hierarchy. Personality and Individual Differences, 99, 22 27. doi:10.1016/j.paid.2016.04.076

Mahmud, Y. \& Swami, V. (2010). The influence of the hijab (Islamic head-cover) on perceptions of women's attractiveness and intelligence. Body Image, 7, 90-93. https://doi.org/10.1016/j.bodyim.2009.09.003 
Martijn, C., Spears, R., Van der Pligt, J., \&Jakobs, E. (1992). Negativity and positivity effects in personperception and inference: Ability versus morality. European Journal of Social Psychology, 22, 453 - 463. https://doi.org/10.1002/ejsp.2420220504

McArthur, L. Z., \& Baron, R. M.(1983). Toward an ecological theoryof social perception. Psychological Review, 90, 215-238.

Morgeson, F. P., \& Campion, M. A. (1997). Social and cognitive sources of potential inaccuracy in job analysis. Journal of applied psychology,82(5), 627-655. http://dx.doi.org/10.1037/00219010.82.5.627

Murphy, N. A. (2007). Appearing Smart: The Impression management of intelligence, person perception accuracy, and behavior in social interaction. Personality and social psychology bulletin, 33 (3). 325339. https://doi.org/10.1177/0146167206294871

Murphy, N. A., Hall, J. A. \& Colvin, J. A. (2003). Accurate intelligence assessments in social interactions: mediators and gender effects. Journal of personality,71(3), 465- 493. https://doi.org/10.1111/1467-6494.7103008

Najarian, B., \& Soudani, M. (2001). Construction and validation of a scale for the measurement of reality distortion. Journal of education and psychology of Shahid Chamran University of Ahvaz (in Persian), 3 (8), 99-114.

Nater, C. \& Zell, E. (2015). Accuracy of social perception: An integration and review of meta-analyses. Social and Personality Psychology Compass, 9 (9), 481-494, DOI: 10.1111/spc3.12194

Park, W.W. (1990). A review of research on groupthink. Journal of behavioral decision making, 3,229245. https://doi.org/10.1002/bdm.3960030402

Piliavin, J., A., \& Charng, H-W., (1990). Altruism: a review of recent theory and research. Annual review of sociology, 16, 27-65.https://doi.org/ 10.1146/annurev.so.16.080190.000331

Powell, D. M. \& Goffin, R. D. (2009). Assessing personality in the employment interview: the impact of training on rater accuracy. Human performance, 22, 450-465. https://doi.org/10.1080/08952809280903248450

Reynolds, W. M. (1982). Development of reliable and valid short forms of the Marlowe-Crowne Social Desirability scale. Journal of Clinical Psychology, 38, 119-125. https://doi.org/ 10.1002/10974679(198201)38:13.0.CO;2-I

Rule, N. O., Krendl, A. C., Ivcevic, Z., \& Ambady, N. (2013). Accuracy and consensus in judgments of trustworthiness from faces: Behavioral and neural correlates. Journal of Personality and Social Psychology, 104(3), 409-426. doi:10.1037/a0031050

Schmid Mast, M., Bangerte, A., Bulliard, C. \&Aerni, G. (2011). How accurate are recruiters' first impressions of applicants in employment interviews? International journal of selection and assessment, 19 (2), 198-208. https://doi.org/ 10.1111/j.1468-2389.2011.00547.x

Sunstein, C. R. (2002). The law of group polarization. The journal of political philosophy, 10(2), 175195. https://doi.org/ 10.1111/1467-9760.00148

Talamas, S. N., Mavor, K. I., \&Perrett, D. I. (2016). Blinded by beauty: Attractiveness bias and accurate perceptions of academic performance. Plos one, 11(2), 1-18. https://doi.org/10.1371/journal.pone.0148284

Tappin, B. M., \& McKay, R. T. (2017). The illusion of moral superiority. Social psychological and personality science, 8(6), 623-631. https://doi.org/ 10.1177/1948550616673878

Todorov, A., Pakrashi, M., \& Oosterhof, N. N. (2009). Evaluating faces on trustworthiness after minimal time exposure. Social Cognition, 27, 813-833. doi:10.1521/soco.2009.27.6.813 
Todorov, A., Said, C. P., Engell, A. D., \& Oosterhof, N. N. (2008). Understanding evaluation of faces on social dimensions. Trends in Cognitive Sciences, 12(12), 455-460. doi:10.1016/j.tics.2008.10.001

Verardi, S., Dahourou, D., Ah-Kion, G., Bhowon, U., Tseung, C. N., Amoussou-Yeye, D., Adjahouisso, M., Bouatta, C., Cissé, D. D., Mbodji, M., Barry. O., Minga, D., Ondongo, F., Tsokini, D., Rigozzi, C., Meyer de Stadelhofen, F., \& Rossier, J. (2010). Psychometric properties of the Marlowe-Crowne Social Desirability Scale in eight African countries and Switzerland. Journal of Cross-Cultural Psychology, 41(1), 19-34. https://doi.org/10.1177/0022022109348918

Vogt, S., Efferson, C., \& Fehr, E. (2013). Can we see inside? Predicting strategic behavior given limited information. Evolution and Human Behavior, 34(4), 258264. doi:10.1016/j.evolhumbehav.2013.03.003

Wojciszke, B. (2005). Morality and competence in person- and self-perception. European review of social psychology, 16, 155 - 188. http://doi.org/10.1080/10463280500229619

Wojciszke, B., Bazinska, R. \& Jaworski, M. (1998). On the dominance of moral categoriesin impression formation. Personality and social psychology bulletin, 24, 1251-1263. https://doi.org/10.1177/01461672982412001

Wolf, S. (2007), Moral psychology and the unity of the virtues. Ratio; An international journal of analytic philosophy, 20 (2), 145-167. https://doi.org/ 10.1111/j.1467-9329.2007.00354.x

Yardi, S. \& Boyd, D. (2010). Dynamic debates: an analysis of group polarization over time on twitter. Bulletin of science, technology \&society, $30(5) \quad 316 \quad-327$. https://doi.org/10.1177/0270467610380011

YarMohammadian, A. (2007). Ability the Scale 3 of Cattell's intelligence test and Rey-Osterrieth Complex Figure in identification of university students with exceptional talent. Journal of education and psychology of Isfahan University (in Persian), 3(1), 7, 77-94.

Zebrowitz, L. A., \& Collins, M. A. (1997). Accurate social perception at zero acquaintance: The affordances of a Gibsonian approach. Personality and social psychology review, 1, 204223.http://dx.doi.org/ 10.1207/s15327957pspr0103_2

Zebrowitz, L. A., \& Rhodes, G. (2004). Sensitivity to bad genes and the anomalous face overgeneralization effect: Cue validity, cue utilization, and accuracy in judging intelligence and health. Journal of nonverbal behavior, 28,167-185. http://dx.doi.org/10.1023/B:JONB.0000039648.30935.1b

Zebrowitz, L. A., Kikuchi, M., \& Fellous, J. (2007). Are effects of emotion expression on trait impressions mediated by babyfaceness? Evidence from connectionist modeling. Personality and Social Psychology Bulletin, 33(5), 648-662. http://dx.doi.org/10.1177/0146167206297399 